\title{
ANALISIS PENERAPAN SANKSI ADMINISTRASI PADA PELAKSANAAN PENGELOLAAN LIMBAH PADA RUMAH SAKIT UMUM RADEN MATTAHER JAMBI
}

\author{
Ivan Fauzani Raharja \\ Fakultas Hukum Universitas Jambi \\ Email: ivanfauzani007@gmail.com
}

\begin{abstract}
Medical waste is very important to manage properly, this is because medical waste belongs to the category of hazardous and toxic waste. Some of the medical waste is included in the category of hazardous waste and part of it is infectious. In relation to RSUD Raden Mattaher Jambi waste management problem, the ministry of environment giving black label in 2014 means that its waste management is very bad and it can affect the imposition of administrative sanction which will be accepted by RSUD Raden Mattaher Jambi. According to Article 198 of Government Regulation Number 101 Year 2014 on the Management of Hazardous and Toxic Wastes "Any Person who produces B3 Waste, B3 Waste Collector, B3 Waste Carrier, B3 Waste Users, B3 Waste Processors and / or B3 Waste Landmakers conducting Environmental Pollution and / or Destruction of Compulsory Environment implement: a. Environmental Pollution and / or Environmental Degradation; and b. Environmental Function Recovery. Given these laws and regulations, hospital waste management should be guided by applicable regulations. if it is not implemented then the government has the right to impose administrative sanctions on the matter either in the form of revocation of temporary permit or other form which has been determined.
\end{abstract}

Keywords: Waste Management; Administrative Sanctions

\section{ABSTRAK}

Limbah medis sangat penting untuk dikelola secara benar, hal ini mengingat limbah medis termasuk ke dalam kategori limbah berbahaya dan beracun. Sebagian limbah medis termasuk kedalam kategori limbah berbahaya dan sebagian lagi termasuk kategori infeksius. Berkaitan dengan masalah pengelolaan limbah RSUD Raden Mattaher Jambi, kementerian lingkungan hidup memberikan label hitam pada tahun 2014 artinya dalam pengelolaan limbahnya sangat buruk dan hal itu dapat berdampak pengenaan sanksi administrasi yang akan diterima oleh RSUD Raden Mattaher Jambi.Menurut Pasal 198 Peraturan Pemerintah Nomor 101 Tahun 2014 Tentang Pengelolaan Limbah Bahan Berbahaya Dan Beracun "Setiap Orang yang menghasilkan Limbah B3, Pengumpul Limbah B3, Pengangkut Limbah B3, Pemanfaat Limbah B3, Pengolah Limbah B3, dan/atau Penimbun Limbah B3 yang melakukan Pencemaran Lingkungan Hidup dan/atau Perusakan Lingkungan Hidup wajib melaksanakan: a. Penanggulangan Pencemaran Lingkungan Hidup dan/atau Kerusakan Lingkungan Hidup; dan b. Pemulihan Fungsi Lingkungan Hidup. Dengan adanya peraturan perundang- undangan tersebut seharusnya pengelolaan limbah rumah sakit harus berpedoman pada peraturan yang berlaku. apabila hal tersebut tidak diterapkan maka pemerintah berhak mengenakan sanksi administrasi terhadap masalah tersebut baik itu berupa pencabutan izin sementara ataupun bentuk lain yang telah ditetapkan.

\section{Kata Kunci: Pengelolaan Limbah; Sanksi Administrasi}

\section{PENDAHULUAN}

A. Latar Belakang Masalah

Pengelolaan sampah padat medis dan non medis rumah sakit sangat dibutuhkan bagi kenyamanan dan kebersihan lingkungan rumah sakit, karena dapat mencegah timbulnya masalah kesehatan.Keberhasilan sistem pengelolaan sampah padat berkaitan erat dengan prosedur tetap yang dimiliki oleh rumah sakit yang bersangkutan sebagai acuan dari pengelolaan sampah yang berpedoman pada peraturan pemerintah. Limbah medis sangat penting untuk dikelola secara benar, hal ini mengingat limbah medis termasuk ke dalam kategori limbah berbahaya dan beracun. Sebagian limbah medis termasuk kedalam 
kategori limbah berbahaya dan sebagian lagi termasuk kategori infeksius.

Limbah medis berbahaya yang berupa limbah kimiawi, limbah farmasi, logam berat, limbah genotoxic dan wadah bertekanan masih banyak yang belum dikelola dengan baik. Sedangkan limbah infeksius merupakan limbah yang bisa menjadi sumber penyebaran penyakit baik kepada petugas, pasien, pengunjung ataupun masyarakat di sekitar lingkungan rumah sakit. Limbah infeksius biasanya berupa jaringan tubuh pasien, jarum suntik, darah, perban, biakan kultur, bahan atau perlengkapan yang bersentuhan dengan penyakit menular atau media lainnya yang diperkirakan tercemari oleh penyakit pasien. Pengelolaan lingkungan yang tidak tepat akan beresiko terhadap penularan penyakit. Beberapa resiko kesehatan yang mungkin ditimbulkan akibat keberadaan rumah sakit antara lain: penyakit menular (hepatitis, diare, campak, AIDS, influenza), bahaya radiasi (kanker,kelainan organ genetik) dan resiko bahaya kimia. $^{1}$

Sampah dan limbah rumah sakit adalah semua sampah dan limbah yang dihasilkan oleh kegiatan rumah sakit dan kegiatan penunjang lainnya. Secara umum sampah dan limbah rumah sakit dibagi dalam dua kelompok besar, yaitu sampah atau limbah klinis dan non klinis baik padat maupun cair.

Rumah sakit yang akhir-akhir ini mendapat sorotan mengenai pengelolaan limbahnya yaitu Rumah Sakit Umum Daerah Raden Mattaher Jambi, yang dinilai ada yang tidak beres dalam pengelolaan limbah yang dihasilkan dari rumah sakit tersebut. Hal ini diperkuat dari fakta awal yang didapatkan oleh penulis melalui salah satu staf instalasi sanitasi Rumah Sakit Umum Daerah Raden Mattaher Jambi, Sari Banun A.Md.K.L

\footnotetext{
${ }^{1}$ AnsharBonasSilfa,"PengelolaanSampah/Limbah RumahSakitDanPermasalahannya",http://ansharca niago.wordpress.com/tag/pengendalianinfeksi/diaksestanggal12Mei2017
}

mengatakan bahwa program perbaikan instalasi pengelolaan limbah dicanangkan dari tahun 2010-2015. Namun baru di awal tahun 2014 diadakan perbaikan tersebut. Sehingga proses pengelolaan limbah tidak bekerja semaksimal mungkin dan mencemari lingkungan sekitar termasuk mengalir ke Danau Sipin yang menjadi awal kecurigaan warga di sekitar Danau Sipin bahwa limbah RSUD Raden Mattaher telah mencemari air Danau Sipin. Bukan hanya itu saja dari data tahun 2014bahwa insinerator yang digunakan untuk mengelola limbah ada 2 unit yang dimiliki RSUD Raden Mattaher Jambi keadaannya rusak berat sehingga tidak dapat berfungsi untuk pembakaran limbah. Perbaikan dan pembelian alat baru dilakukan tahun 2015, namun izin penggunaanya belum ada dari kementerian lingkungan hidup.

Tidak berhenti disitu juga tercatat hingga tahun 2015 ternyata IPAL RSUD Raden Mattaher Jambi belum memiliki izin resmi.hal ini terbukti saat BLHD Propinsi jambi melakukan pengecekan terhadap IPALnya yang sudah cukup baik namun malah tidak berizin. ${ }^{2}$ Bahkan karena adanya pembangunan gedung baru yang telah berjalan sejak tahun 2014 maka perlu perubahan pada dokumen lingkungan. Dokumen lingkungan yang saat ini dimiliki RSUD Raden Mattaher Jambi hanya dokumen UKL dan UPL dan belum memiliki Dokumen AMDAL.Mereka baru mengurus AMDAL tahun 2015.

Jika masalah ini dibiarkan terus menerus maka dampaknya akan semakin besar terutama kepada orang-orang yang berada disekitar Rumah Sakit baik pasien, tenaga medis, maupun warga yang berada disekitar Rumah Sakit tersebut. Untuk itu perlu adanya tindakan pemerintah terkait masalah tersebut dengan menerapkan sanksi administrasi terhadap pelanggaran

\footnotetext{
${ }^{2}$ http://harianjambi.com iaksesRabu,4Februari2015
} 
yang dilakukan oleh Rumah Sakit Umum Daerah Raden Mattaher Jambi.

Undang-Undang Nomor 44 Tahun 2009 Tentang Rumah Sakit Pasal 54 ayat 5 dijelaskan bahwa"dalam rangka pembinaan dan pengawasan, Pemerintah Daerah dapat mengambil tindakan administratif yaitu berupa teguran lisan, teguran tertulis, dan/atau denda dan pencabutan izin".

Mengenai sanksi administrasi yang dikenakan terhadap pengelolaan limbah Rumah Sakit Umum Daerah Raden Mattaher Jambi temasuk ke dalam pelanggaran kerusakan lingkungan hidup karena RSUD Raden Mattaher Jambi dalam melakukan pengelolaan limbah B3 tidak sesuai aturan yang berlaku dalam peraturan perundang-undangan.

Berkaitan dengan masalah pengelolaan limbah RSUD Raden Mattaher Jambi,kementerian lingkungan hidup memberikan label hitam pada tahun 2014 artinya dalam pengelolaan limbahnya sangat buruk dan hal itu dapat berdampak pengenaan sanksi administrasi yang akan diterima oleh RSUD Raden Mattaher Jambi.

$$
\text { Badan Lingkungan Hidup }
$$

PropinsiJambi dalam hal ini berwenang dalam pengambilan tindakan terhadap pelanggaran lingkungan yang terjadi pada Rumah Sakit Umum Daerah Raden Mattaher Jambi.Hal ini sesuai dengan Keputusan Presiden Nomor 10 Tahun 2000 Tentang Badan Pengendalian Dampak Lingkungan Pasal 2: "Bapedal mempunyai tugas menyelenggarakan tugas uтum pemerintahan dan pembangunan di bidang pengendalian dampak lingkungan hidup yang meliputi pencegahan dan penanggulangan pencemaran dan kerusakan lingkungan hidup serta pemulihan kualitas lingkungan hidup dalam penyusunan kebijakan teknis dan program pengendalian dampak lingkungan sesuai dengan peraturan perundang-undangan yang berlaku".
Selanjutnya dalam Peraturan Menteri Lingkungan Hidup Nomor 3 Tahun 2014 Tentang Program Penilaian Peringkat Kinerja Perusahaan Dalam Pengelolaan Lingkungan Hidup Pasal 15 angka (1) : Dalam melaksanakan PROPER, Menteri dapat melimpahkan sebagian kewenangan dalam pelaksanaan PROPER kepada gubernur sesuaidengan kewenangannya.

Sedangkan peraturan yang dilanggar mengenai pencemaran limbah dalam hal ini yang terjadi pada RSUD Raden Mattaher Jambi setelah dibuktikan oleh BLHD Propinsi Jambi saat melakukan pengecekan dan pengumpulan fakta dilapangan yaitu Pasal198 Peraturan Pemerintah Nomor 101 Tahun2014 Tentang Pengelolaan Limbah Bahan Berbahaya Dan Beracun : "Setiap Orang yang menghasilkan Limbah B3, Pengumpul Limbah B3, Pengangkut Limbah B3, Pemanfaat Limbah B3, Pengolah Limbah B3, dan/atau Penimbun Limbah B3 yang melakukan Pencemaran Lingkungan Hidup dan/atau Perusakan Lingkungan Hidup wajib melaksanakan:

a. PenanggulanganPencemaran

Lingkungan Hidup dan/atau

Kerusakan Lingkungan Hidup; dan

b. Pemulihan Fungsi Lingkungan Hidup

Dengan adanya peraturan perundang-undangan tersebut seharusnya pengelolaan limbah rumah sakit harus berpedoman pada peraturan yang berlaku.apabila hal tersebut tidak diterapkan maka pemerintah berhak mengenakan sanksi administrasi terhadap masalah tersebut baik itu berupa pencabutan izin sementara ataupun bentuk lain yang telah ditetapkan

\section{B. Perumusan Masalah}

Berdasarkanlatarbelakangdiatas,ma kadapatdirumuskanpermasalahannya sebagai berikut:

1. Bagaimanakah Kondisi EmpirikPengolahan Limbah di RSUD Raden Mattaher Jambi? 
2. Bagaimanakah mekanisme pemberian sanksi administrasi terhadap pengelolaan limbah pada Rumah Sakit Umum Daerah Raden Mattaher Jambi?

\section{TUJUAN DAN MANFAAT PENELITIAN}

\section{Tujuan Penelitian}

a. Untuk mengetahui mekanisme pemberian sanksi administrasi terhadap pengelolaan limbah pada Rumah Sakit Umum Daerah Raden Mattaher Jambi.

b. Untuk memberikan rekomendasi tentang upaya efektivikasi sanksi administrasi dalam pelanggaran pengelolaan limbah berbahaya.

2. Manfaat Penelitian

Secara teoritis hasil Penelitian ini diharapkan dapat memberikan sumbangan pemikiran dalam pengembangan ilmu hukum pada umumnya dan hukum lingkungan pada khususnya mengenai penegakan sanksi administrasi pengelolaam limbah di bidang perlindungan dan pengelolaan lingkungan hidup.

\section{METODE PENELITIAN}

1. Lokasi Penelitian: Rumah Sakit Umum Daerah Raden Mattaher Jambi khususnya di bagian sanitasi rumah sakit tersebut untuk memperoleh fakta awal dalam penulisan skripsi ini. Selain itu penulis juga mengambil data laporan pengumpulan bahan dan keterangan mengenai pengelolaan limbah RSUD Raden Mattaher Jambi pada kantor BLHD Propinsi Jambi dan data dokumen evaluasi lingkungan RSUD Raden Mattaher Jambi pada BLH Kota Jambi sebagai sumber informasi.

2. Tipe Penelitian: Tipe penelitian yang dilakukan adalah penelitian yuridis empiris, karena dalam penelitian ini penulis mencoba menyoroti bagaimana penerapan sanksi administrasi terhadap pengelolaan limbah Rumah Sakit Umum Daerah Raden Mattaher Jambi, serta apakah dalam pengelolaan limbahnya tersebut sudah sesuai dengan peraturan perundang- undangan yang berlaku (dassollen dassein).

3. Pengumpulan dan Analisis Data: analisis data secara kualitatif dan menarik kesimpulan dalam bentuk deskriptif dengan memaparkan mengenai penerapan sanksi administrasi oleh pemerintah terhadap pengelolaan limbah di Rumah Sakit Umum Daerah Raden Mattaher Jambi

\section{PEMBAHASAN}

DalamUndang-Undang

Perlindungan dan Pengelolaan Lingkungan Hidup telah dijelaskan bahwa tindakan atas terjadinya pencemaran limbah yang menyebabkan kerusakan lingkungan hidup dapat dikenakan sanksi administrasi yaitu berupa teguran tertulis, paksaan pemerintah, pembekuan izin lingkungan, dan pencabutan izin lingkungan. Dalam Peraturan Menteri Lingkungan Hidup Nomor 02 Tahun2013 Tentang Pedoman Penerapan Sanksi Administratif di Bidang Perlindungan Pengelolaan Lingkungan Hidup menjelaskan bahwa penerapan sanksi administrasi dilakukan apabila:

1) tidak memiliki izin perlindungan dan pengelolaan lingkungan hidup;

2) tidak memiliki izin lingkungan;

3) tidak memiliki dokumen lingkungan;

4) tidak menaati persyaratan izin perlindungan dan pengelolaan lingkungan hidup;

5) tidak menaati kewajiban dan/atau perintah sebagaimana tercantum dalam izin perlindungan dan pengelolaan lingkunganhidup; dan/atau

6) tidak membuat dan menyerahkan laporan pelaksanaanterhadap pelaksanaan persyaratan dan kewajiban lingkungan hidup.

Beberapa peraturan perundangundanganmengenai sanksi administrasi pencemaran limbah rumah sakit.

a. Peraturan Pemerintah Nomor 101 Tentang Pengelolaan Limbah Bahan Berbahaya Dan Beracun. 
b. Peraturan Pemerintah Nomor 82 Tahun 2001 Tentang Pengelolaan Kualitas Air Dan Pengendalian Pencemaran Air.

c. Peraturan Pemerintah Nomor 27 Tentang Pengelolaan Limbah Radioaktif. d. Peraturan Menteri Lingkungan Hidup Nomor 02 Tahun 2013 Tentang Pedoman Penerapan Sanksi Administrasi DiBidang Perlindungan Dan Pengelolaan Lingkungan Hidup.

e. Peraturan Menteri Lingkungan Hidup Nomor 5 Tahun2014 Tentang Baku Mutu Air Limbah

Prosedur menunjuk pada tahapantahapan yang harus ditempuh dalam pembuatan keputusan sehubungan dengan penggunaan wewenang paksaan pemerintah. Kewenangan pemerintah untuk menggunakan paksaan merupakan kewenangan yang bersifat bebas, dalam arti pemerintah diberi kebebasan untuk mempertimbangkan menurut inisiatifnya sendiri apakah mengunakan paksaan atau tidak atau bahkan menerapkan sanksi lainnya. Dengan kata lain bahwa kewenangan pemerintah dalam menerapkan paksaan sebagai sanksi dalam hukum administrasi harus sesuai dengan apa yang dilanggar dengan ketentuan aturan yang berlaku.

Jenis-Jenis Limbah Rumah Sakit

Bedasarkan potensi bahaya yang terkandung dalam limbah klinis, maka jenis limbah dapat digolongkan sebagai berikut:
a. Limbah Benda Tajam
b. Limbah Infeksius
c. Limbah Jaringan Tubuh
d. Limbah Sitotoksik
e. Limbah Farmasi
f. Limbah Kimia
g. Limbah Radioaktif

Apabila baku mutu tidak terpenuhi atau bila jumlah zat atau energi tertentu yang masuk kemedia lingkungan melebihi daya dukung lingkungan, maka media lingkungan sudah dirusak atau sudah mengalami degradas yang bisa membahayakan kehidupan.
Hal ini lah yang menjadi pemicu terjadinya pencemaran limbah rumah sakit karena dalam pengelolaan limbahnya terdapat kesalahan dan bahkan tidak sesuai dengan aturan yang berlaku.

1. Kondisi Empirik Pengolahan Limbah di RSUD Raden Mattaher Jambi

Kementerian Lingkungan Hidup memberikan PROPER (Program Penilaian Peringkat Kinerja Perusahaan) Hitam pada tahun 2014 terhadap RSUD Raden Mattaher Jambi. Hal ini telah dibuktikan atas pengumpulan data oleh BLHD Propinsi Jambi pada tanggal 29 Juni -1 Juli 2015 untuk memperjelas bahwa PROPER yang diterima RSUD Raden Mattaher Jambi dari Kementerian Lingkungan Hidup tersebut sesuai dengan temuand ilapangan dan dapat ditindak lanjuti pada tahun 2015. Sebelumnya pada tahun 2012-2013 RSUD Raden Mattaher Jambi telah Mendapat PROPER Merah.Itu artinya sudah ada penegakan sanksi administrasi yang diberikan Kementerian Lingkungan Hidup kepada RSUD Raden Mattaher Jambi. Hal ini berdasarkan pada data:

1. RSUD Raden Mattaher Jambi tidak mempunya izin pengolahan limbah B3 (limbah medis) dari Kementerian Lingkungan Hidup dan Kehutanan dengan mempergunakan incenerator yang baru.

2. Abu incenerator yang dihasilkan disimpan di tempat yang tidak sesuai dengan peraturan yang berlaku terutama di dalam pengemasan, simbol, dan label.

3. Ditemukan limbah B3 (limbah medis berupa jarum suntik) yang masih dicampur ke dalam limbah domestik dan dibuang ke lingkungan.

4. RSUD Raden Mattaher belum melakukan pamasangan sampling hole pada genset kapasitas 1500 kVA sebagai upaya melakukan pengendalian pencemaran udara.

5. Tidak melakukan ukur debit air limbah karena kapasitas saluran terlalu luas. 
6. Pada hasil pemeriksaan sampel air bersih pada bulan Desember 2014, air yang digunakan di RSUD Raden Mattaher Jambi, 20\% nya belum memenuhi persyaratan karena dari 10 titik sampling, masih ada 2 titik yang kadar airnya melebihi batas maksimum yang diperbolehkan.

8. Kerusakan pada Tempat Pembuangan Sampah Sementara (TPS) domestik sehingga perlu adanya perbaikan.

9. IPAL lama yang dimiliki RSUD Raden Mattaher Jambi sudah tidak efektif untuk mengolah limbah cair, sehingga perlu dilaksanakan pengadaan IPAL baru.

10. Incenerator lama yang dimiliki RSUD Raden Mattaher Jambi sudah tidak layak pakai, sehingga perlu dilaksanakan pengadaan incenerator baru.

11. Dengan adanya kerusakan alat pengelolaan limbah tersebut, RSUD Raden Mattaher tidak segera melapor ke instansi terkait. Setelah dilakukan pergantian alat pengelolaan limbah yang baru juga terjadi hal yang serupa.Pihak RSUD Raden Mattaher Jambi tidak mengurus izin penggunaan IPAL dan Incenerator yang baru namun pengolahan limbah tetap dilakukan. Izin baru diurus setelah adanya pengecekan Tim Kementerian Lingkungan Hidup saat akan melakukan penilaian PROPER.

12. Pemeriksaan kualitas limbah cair.

Berdasarkan data-data diatas tersebut, Kementerian Lingkungan Hidup memberikan PROPER (Program Penilaian Peringkat Kinerja Perusahaan) Hitam pada tahun 2014. Hal ini telah dibuktikan atas pengumpulan data oleh BLHD Propinsi Jambi pada tanggal 29 Juni-1 Juli 2015 untuk memperjelas bahwa PROPER yang diterima RSUD Raden Mattaher Jambi dari Kementerian Lingkungan Hidup tersebut sesuai dengan temuan di lapangan dan dapat ditindak lanjuti pada tahun 2015. Sebelunya pada tahun 2012-2013 RSUD Raden
Mattaher Jambi telah Mendapat PROPER Merah. Itu artinya sudah ada penegakan sanksi administrasi yang diberikan Kementerian Lingkungan Hidup kepada RSUD Raden Mattaher Jambi.hal ini sesuai dengan Peraturan Menteri Lingkugan Hidup Nomor 03 Tahun 2014 Tentang Program Penilaian Peringkat Kinerja Perusahaan Dalam Pengelolaan Lingkungan Hidup Pasal 17 huruf a : Terhadap penanggung jawab usaha dan latau kegiatan yang ditetapkan sebagai peringkat merah dua kali untuk penilaian PROPER yang sama Menteri mengenakan sanksi administrasi.

Dalam peraturan tersebut tidak disebutkan dalam bentuk apa sanksi administrasi yang diberikan kepada RSUD Raden Mattaher Jambi terkait PROPER Merah yang diterima tersebut. Hanya saja saat tahun 2014 RSUD Raden Mattaher Jambi mendapat PROPER Hitam dari Kementerian Lingkungan Hidup karena terkait izin dokumen lingkungan yang belum direvisi dan belum adanya Dokumen AMDAL (Analisis Mengenai Dampak Limkungan).

Berkaitan dengan hal tersebut, mengacu pada Peraturan Menteri Lingkungan Hidup Nomor 05 Tahun 2012 Tentang Jenis Usaha Dan/Atau Kegiatan Yang Wajib Memiliki Analisis Mengenai Dampak Lingkungan Hidup, kegiatan RSUD Raden Mattaher Jambi merupakan kegiatan wajib AMDAL.

Aktifitas yang terjadi di RSUD Raden Mattaher Jambi diprakirakan dapat menimbulkan perubahan terhadap komponen lingkungan baik fisik kimia, flora, fauna, biota air, maupun sosial, ekonomi dan budaya sehingga untuk mengantisipasi timbulnya permasalahan dan atau dampak lingkungan akibat adanya kegiatan tersebut, maka Dinas Pekerjaan Umum Propinsi Jambi selaku pemrakarsa kegiatan bermaksud melakukan studi dan penyusunan 
Analisis Mengenai Dampak Lingkungan Hidup (AMDAL). ${ }^{3}$

Maka selanjutnya RSUD Raden Mattaher Jambi wajib menyusun Dokumen Evaluasi Lingkungan Hidup (DELH) dan dilaporkan kepada Badan Lingkungan Hidup Kota Jambi selaku instansi yang berwenang atas penataan lingkungan hidup di Kota Jambi.

Jika dilihat dari beberapa pelanggaran yang dilakukan RSUD Raden Mattaher Jambi, maka dasar hukum peraturan perundang-undangan untuk menerapkan sanksi administrasi terhadap RSUD Raden Mattaher jambi terkait pelanggaran mengenai pengelolaan limbah yaitu Peraturan Menteri Lingkungan Hidup Nomor 02 Tahun 2013 Tentang Pedoman Penerapan Sanksi Administrasi Di bidang Perlindungan Dan Pengelolaan Lingkungan Hidup.

Jika dikaji dari PROPER yang telah diperoleh RSUD Raden Mattaher Jambi, dua kali mendapat PROPER Merah yaitu tahun 2012-2013 dan PROPER Hitam satu kali yaitu tahun 2014 berdasarkan dari data-data yang telah diperoleh berdasarkan kriteria penilaian PROPER Merah dan Hitam Berdasarkan kriteria penilaian PROPER tersebut maka RSUD Raden Mattaher mendapat sanksi administrasi dalam bentuk Teguran tertulis dan paksaan pemerintah yang mana telah sesuai dengan pelanggaran yang diperbuat oleh RSUD Raden Mattaher Jambi.

2. MekanismePemberian Sanksi Administrasi Pengelolaan Limbah Rumah Sakit Umum Daerah Raden Mattaher Jambi

Sebelum membahas mengenai mekanisme penerapan sanksi administrasi terhadap pengelolaan limbah pada RSUD Raden Mattaher Jambi, sebaiknya harus diketahui terlebih dahulu mengenai prosedur penerapan sanksi administrasi sebagai langkah awal untuk mekanisme penerapan sanksi administrasi.

${ }^{3}$ Ibid. Hal. 5
Berikut prosedur penerapan sanksi administrasi berdasarkan Peraturan Menteri Lingkungan Hidup Nomor 02 Tahun 2014 Tentang Pedoman Penerapan Sanksi Administrasi Di Bidang Perlindungan Dan Pengelolaan Lingkungan Hidup, mekanisme penerapan sanksi administratif :

1. Prosedur atau tata cara penerapan sanksi yang dijalankan harus dipastikan sesuai dengan peraturan yang menjadi dasarnya dan Asas-asas Umum Pemerintahan yang Baik.

2. Pejabat yang menerapkan sanksi administratif harus dipastikan memiliki kewenangan yang sah berdasarkan peraturan perundang-undangan. Kewenangan tersebut dapat bersumber dari atribusi, delegasi, atau mandat. Sumber kewenangan ini akan menentukan cara bagaimana pejabat administratif menjalankan kewenangannya.

Dalam hal ini Walikota Jambi selaku pejabat administrasi kota jambi berwenang dalam menjalankan kewenangannya yang bersumber atas kewenangan delegasi menerapkan sanksi administrasi kepada RSUD Raden Mattaher Jambi.

Mengenai penerapan sanksi administrasi pada RSUD Raden Mattaher Jambi maka yang berwenang melakukan penerapan sanksi administrasi yaitu Walikota Jambi melalui Badan Lingkungan Hidup Kota Jambi selaku instansi yang mengelola lingkungan hidup di Kota Jambi. Kewenangan ini diberikan kepada pemerintah kota dalam hal ini RSUD Raden Mattaher Jambi berlokasi di Jambi dan izin opereasionalnya dikeluarkan oleh pemerintah Kota Jambi yakni Walikota selaku pejabat kepala daerah Kota Jambi. Selanjutnya BLH Kota Jambi selaku lembaga teknis daerah yang melaksanakan tugas di bidang lingkungan hidup Kota Jambi berhak melaksanakan tugas penerapan sanksi administrasi di bidang lingkungan hidup setelah adanya surat keputusan dari walikota yang berbentuk KTUN. 
3. Ketetapan Penerapan Sanksi

Administratif

Ketetapan penerapan sanksi

administratif yang digunakan dalam penerapan sanksi administratif meliputi :

a. ketetapan bentuk hukum

b. Sanksi administratif ditujukan kepada perbuatan pelanggaran penanggung jawab usaha dan/atau kegiatan, maka instrumen yang digunakan untuk menerapkan sanksi administratif harus dipastikan berbentuk Keputusan Tata Usaha Negara (KTUN).

b. ketetapan substansi

Ketetapan substansi dalam penerapan sanksi administratif berkaitan dengan kejelasan tentang a). jenis dan peraturan yang dilanggar $b$ ). jenis sanksi yang diterapkan, c). perintah yang harus dilaksanakan d). jangka waktu, e). konsekuensi dalam hal sanksi administratif tersebut tidak dilaksanakan dan, f). hal-hal lain yang relevan

Berkaitan dengan pelanggaran yang dilakukan RSUD Raden Mattaher Jambi telas jelas jenis pelanggaran yang dilakukan namun sejauh ini sanksi yang diterapkan oleh instansi terkait belum jelas bahkan tidak diterapkan sehingga mengenai perintah yang harus dilaksanakan belum terlaksana.

c. Kepastian tiadanya cacat yuridis dalam penerapan sanksi

Dalam Keputusan Tata Usaha Negara hindari klausula pengaman yang lazimnya berbunyi : "Apabila dikemudian hari ternyata ada kekeliruan di dalam Keputusan ini, maka akan diperbaikai sebagaimana mestinya".

d. Asas Kelestarian dan Keberlanjutan

Dalam menerapkan sanksi administratif perlu mempertimbangkan asas kelestarian dan keberlanjutan.Asas kelestariandan keberlanjutan adalah bahwa setiap orang memikul kewajiban dan tanggung jawab terhadap generasi mendatang dan terhadap sesamanya dalam melakukan upaya pelestarian daya dukung ekosistem dan memperbaiki kualitas lingkungan hidup.

RSUD Raden Mattaher telah melakukan upaya untuk melestarikan lingkungan dengan memperbaiki alat pengelolaan limbah dan bekerja sama dengan pihak ketiga dalam pengelolaan limbah B3 yaitu CV. Surya Jaya Logam.

Berdasarkan PeraturanMenteri Lingkungan Hidup Nomor 02 Tahun 2014 Tentang Pedoman Penerapan Sanksi Administrasi Di Bidang Perlindungan Dan Pengelolaan Lingkungan Hidup, mekanisme penerapan sanksi administratif meliputi :

a. Bertahap

Penerapan sanksi administratif secara bertahap yaitu penerapan sanksi yang didahului dengan sanksi administratif yang ringan hingga yang terberat. Apabila teguran tertulis tidak ditaati maka ditingkatkan penerapan sanksi administratif berikutnya yang lebih berat yaitu paksaan pemerintah atau pembekuan izin. Apabila sanksi paksaan pemerintah atau pembekuan izin tidak ditaati maka dapat dikenakan sanksi yang lebih berat lagi yaitu sanksi pencabutan izin.

b. Bebas (tidak bertahap)

Penerapan sanksi administratif secara bebas yaitu adanya keleluasan bagi pejabat yang berwenang mengenakan sanksi untuk menentukan pilihan jenis sanksi yang didasarakan pada tingkat pelanggaran yang dilakukan oleh penanggung jawab usaha dan/atau kegiatan. Apabila pelanggaran yang dilakukan oleh penanggung jawab usaha dan/atau kegiatan sudah menimbulkan pencemaran dan/atau kerusakan lingkungan hidup, maka dapat langsung dikenakan sanksi paksaan pemerintah.Selanjutnya jika sanksi administratif paksaan pemerintah tidak dilaksanakan maka dikenakan sanksi pencabutan izin tanpa didahului dengan sanksi teguran tertulis.

c. Kumulatif 
Penerapan sanksi administratif secara kumulatif terdiri atas kumulatif internal dan kumulatif eksternal. kumulatif internal adalah penerapan sanksi yang dilakukan dengan menggabungkan beberapa jenis sanksi administratif pada satu pelanggaran. Misalnya sanksi paksaan pemerintah digabungkan dengan sanksi pembekuan izin.

Kumulatif eksternal adalah penerapan sanksiyang dilakukan dengan menggabungkan penerapan salah satu jenis sanksi administratif dengan penerapan sanksi lainnya, misalnya sanksi pidana. Selanjutnya penerapan sanksi administratif ditetapkan dengan menggunakan keputusan tata usaha negara yang memuat paling sedikit:

a. nama jabatan dan alamat pejabat administrasi yang berwenang;

Sanksi administrasi harus dijatuhkan oleh organ administrasi yang berwenang. Dalam hal ini pejabat yang bersangkutan harus mempunyai wewenang yang sah berdasarkan peraturan perundang-undangan. Tanpa kewenangan yang sah, seseorang tidak dapat melakukan tindakan hukum publik. $^{4}$

Dalam hal ini yaitu pejabat administrasi yang berwenang menerapkan sanksi administrasi terhadap RSUD Raden Mattaher Jambi ialah Walikota Jambi.

c. nama dan alamat penanggung jawab usaha dan/atau kegiatan;

d. penanggungjawab usaha dan/atau kegiatan dalam hal ini ialah Direktur RSUD Raden Mattaher Jambi.

c. nama dan alamat perusahaan;

Dalam hal ini ialah RSUD Raden Mattaher Jambi yang beralamat di jalan LetjenSoepraptoNomor31KelurahanTel anaiPuraKecamatanTelanai Pura Kota Jambi.

d. jenis pelanggaran;

\footnotetext{
${ }^{4}$ Bachrul Amiq, Op.Cit.,hal.45.
}

\begin{abstract}
Mengenai jenis pelanggaran telah jelas yaitu mengenai pengelolaan limbah yang dihasilkan RSUD Raden Mattaher Jambi
\end{abstract}

e. ketentuan yang dilanggar baik ketentuan yang diatur dalam peraturan perundangundangan maupun persyaratan dan kewajiban yang dimuat dalam izin lingkungan; mengenai ketentuan yang dilanggar oleh RSUD Raden Mattaher Jambi baik ketentuan yang diatur dalam peraturan perundang-undangan maupun persyaratan dan kewajiban yang dimuat dalam izin lingkungan.

f. ruang lingkup pelanggaran; ruang lingkup pelanggaran yang dilakukan RSUD Raden Mattaher Jambi dalam hal ini ialah meliputi pelanggaran lingkungan hidup khususnya mengenai pengelolaan limbah.

g. uraiankewajiban atau perintah yang harus dilakukan penanggung jawab usaha dan/atau kegiatan; RSUD Raden Mattaher Jambi diwajibkan mengurus izin lingkungan seperti AMDAL, dan izin penggunaan alat pengolahan limbah yang baru seperti IPAL dan incinerator.Kemudian memperbaiki kesalahan dalam pengelolaan limbah B3 agar tidak ada lagi yang dibuang ke lingkungan.

h.

jangkawaktupenaatankewajibanpenanggun gjawabusahadan/atau kegiatan;

mengenai jangka waktu ditetapkan oleh yang memberikan sanksi administrasi dalam hal ini Walikota Jambi yang tertuang dalam Keputusan Tata Usaha Negara.

i.ancaman sanksi yang lebih berat apabila tidak melaksanakan perintah dalam sanksi teguran tertulis;

Ancaman sanksi yang lebih berat apabila sanksi teguran tertulis tidak diindahkan maka sanksi administrasi yang lebih berat selanjutnya akan dikenakan. Dalam hal ini seharusnya RSUD Raden Mattaher Jambi sudah dapat dikenakan sanksi yang lebih berat lagi 
yaitu sanksi administrasi dalam bentuk paksaan pemerintah karena terkait izin dokumen lingkungan dan izin penggunaan alat pengolahan limbah belum ada tetapi tetap melakukan kegiatan pengolahan limbah.

Melihat dari fakta yang diketahui mengenai pelanggaran pengelolaan limbah yang dilakukan oleh RSUD Raden Mattaher Jambi bahwa penegakan hukum terhadap pelanggaran tersebut belum secara jelas.Yang jadi persoalannya sekarang ialah apakah sanksi tersebut telah benar-benar ditegakkan atau tidak. Dari informasi yang didapat bahwa pengehentian sementara terhadap pembangunan gedung baru merupakan penerapan sanksi administrasi yang diberikan oleh Kementerian Lingkungan Hidup terhadap RSUD Raden Mattaher Jambi. Namun mengapa tidak ada penerapan sanksi administrasi dari pemerintah daerah terkait masalah ini.Status RSUD Raden Mattaher Jambi yang memang milik pemerintah daerah mungkin menjadi kendala mengapa sulit untuk menerapkan sanksi administrasi sehingga harus dari pusat yang menerapkannya. Mereka mungkin menganggap karena itu rumah sakit milik sendiri sehingga tidak perlu adanya tindak lanjut dari masalah tersebut.

Disinilah terjadi ketimpangan antara yang seharusnya (dassollen) dan kenyataannya (dassein) bahwa selama ini pemerintah daerah khususnya Kota Jambi tidak menegakkan sanksi administrasi tersebut. Seolah-olah pemerintah selama ini hanya menganggap masalah ini biasa saja padahal ini menyangkut lingkungan hidup dimana dapat membahayakan lingkungan dan mahluk hidup didalamnya.

\section{PENUTUP}

1. Kesimpulan

Berdasarkan hasil penelitian yang telah dikemukakan diatas, maka dapat disimpulkan sebagai berikut :

1. Bentuk sanksi administrasi yang diterapkan oleh Pemerintah Daerah dalam hal ini Kota Jambi terhadap
RSUD Raden Mattaher Jambi belum ada, meski dalam peraturan perundangundangan jelas tertulis mengenai bentuk sanksi administrasi terkait pengelolaan limbah.

2. Mekanisme penerapan sanksi administrasi terhadap RSUD Raden Mattaher Jambi melalui Penegakan PROPER Rumah Sakit yang dilakukan Kementerian Lingkungan Hidup Republik Indonesia.

2. Saran

1. Dalam melakukan pengelolaan limbah, RSUD Raden Mattaher Jambi seharusnya memperhatikan aturan yang berlaku dalam peraturan perundang-undangan agar tidak terjadi pelanggaran yang dapat membahayakan lingkungan hidup sehingga RSUD Raden Mattaher Jambi dapat memberikan pelayanan terbaik bagi kesehatan masyarakat.

2. Pemerintah daerah dalam hal ini harus tegas segera mengambil tindakan apabila ditemukan adanya pelanggaran terkait pengelolaan limbah RSUD Raden Mattaher Jambi terlepas dari status rumah sakit milik pemerintah daerah. Hal ini penting mengingat fungsi rumah sakit sebagai tempat pelayanan kesehatan. Oleh karena itu penerapan sanksi administrasi perlu dilakukan agar RSUD Raden Mattaher Jambi dapat lebih baik lagi dalam melakukan pengelolaan limbahnya dan meminimalisir apabila telah terjadi pencemaran akibat kesalahan dalam pengelolaan limbah yang dihasilkan dari kegiatan rumah sakit.

\section{DAFTAR PUSTAKA}

Anshar Bonas Silfa, "Pengelolaan Sampah/Limbah Rumah Sakit Dan Permasalahannya",

Bahder Johan Nasution,Metode penelitian IlmuHukum,MandarMaju,Bandung, 2008.

Sukanda Husin,Penegaka nHukum Lingkungan Indonesia, Cet.2SinarGrafika, Jakarta, 2009

World Health Organization (WHO) dan Kementerian Keseharan RI, Modul 
Ivan Fauzani Raharja, Analisis Penerapan Sanksi Administrasi Pada Pelaksanaan Pengelolaan Limbah Pada Rumah Sakit Umum Raden Mattaher Jambi

Halaman 353-363

Peningkatan Kapasitas Dalam Pengelolaan Limbah Medis, Jakarta, 2013.

Wiku Adisasmito, Sistem Manajemen Lingkungan Rumah Sakit, RajaGrafindo Persada, Jakarta, 2009

http://ansharcaniago.wordpress.com/tag/pe ngendalian-infeksi/diaksestanggal12 Mei 2014.

http://harian jambi.com diakses Rabu, 4 Februari 2015 http://patriotismemuda.blogspot.co.i $\mathrm{d} / 2013 / 12 /$ makalah-perlindungan

hukumterhadap.htmldiakses Tanggal 6 Oktober 2015 